\title{
Pentecostalismo e política: o envolvimento político da Assembleia de Deus do Amapá
}

\author{
Arielson Teixeira do Carmo ${ }^{1}$ \\ Marcos Vinicius de Freitas Reis ${ }^{2}$ \\ Cleiton de Jesus Rocha ${ }^{3}$
}

\section{RESUMO}

No cenário Amapaense, a denominação Assembleia de Deus se mobiliza politicamente para eleger seus representantes desde o início da década de 90, seguindo a mobilização evangélica em nível nacional com o slogan "irmão vota em irmão", que busca eleger políticos do segmento evangélico. Caracterizando-se como sendo a maior denominação evangélica pentecostal do estado do Amapá (100.821 membros segundo dados do IBGE 2010), a AD se mobiliza politicamente para eleger seus pares e garantir seus interesses. Nesse contexto, a presente pesquisa tem como objetivo investigar o apoio assembleiano dado para políticos do legislativo no Amapá, desvendando como se dá a escolha do candidato e como se articula o apoio a esses parlamentares. Para melhor fundamentar a pesquisa, analisa-se a relação entre religião e política no Brasil, com atenção

1 Mestrando do Programa de Pós-Graduação em Sociologia da Universidade Federal de Pelotas - UFPel. Graduado do Curso de Licenciatura e Bacharelado em Ciências Sociais da Universidade Federal do Amapá - UNIFAP. Membro do Centro de Estudos Políticos Religião e Sociedade - CEPRES. E-mail: arielsondocarmo@gmail.com.

2 Doutor em Sociologia pela Universidade Federal de São Carlos. Docente do Curso de Graduação em Relações Internacionais da Universidade Federal do Amapá (UNIFAP). Docente da Especialização Estudos Culturais e Políticas Públicas. Possui graduação em História pela Universidade Federal de Uberlândia (UFU) e mestrado em Ciência Política pela Universidade Federal de São Carlos (Ufscar). Membro do Núcleo de Estudos de Religião, Economia e Política (NEREP). Pesquisador do Observatório em Direitos Humanos da Amazônia (OBADH). Líder do Centro de Estudos Políticos, Religião e Sociedade (CEPRES). Tesoureiro da Associação Nacional de Historiadores Sessão Amapá (ANPUH AP). Filiado a Associação Brasileira de Historiadores da Religião (ABHR). Coordenador da ABHR Região Norte. E-mail: marcosvinicius5@yahoo.com.br

3 Graduando em Licenciatura em Sociologia na Universidade Federal do Amapá (UNIFAP). Foi Bolsista voluntário do Grupo PET - Programa de Educação Tutorial; Bolsista de Iniciação Cientifica - PROBIC - UNIFAP. Membro do Centro de Estudos Políticos, Religião e Sociedade (CEPRES). E-mail: clei2014cs@hotmail.com 
para a expansão evangélica pentecostal, em especial da Assembleia de Deus, que, através da mudança de postura, proselitismo e atuação política resultou na multiplicação de espaços sociais ocupados por essa denominação na sociedade brasileira, não se diferenciando no Amapá, estado em que mudou sua postura política na tentativa de legitimar-se socialmente e politicamente. No estado, a AD trabalha sob duas perspectivas, tanto com candidaturas oficiais quanto com apoio político. Existe uma heterogeneidade com relação a este apoio devido às próprias fragmentações e cisões internas, fazendo com que AD não consiga sozinha eleger um candidato a partir de sua membresia. Por meio do tema em questão, os pressupostos teóricos metodológicos da pesquisa concentram-se em pesquisa do tipo qualitativa, onde as técnicas empregadas são análises de conteúdo, entrevistas semiestruturadas e revisão bibliográfica.

Palavras-chave: Insurgência pentecostal na política. Assembleia de Deus no Estado do Amapá. Apoio Político. Candidaturas oficiais.

\title{
PENTECOSTALISM AND POLITICS: THE POLITICAL INVOL- VEMENT ASSEMBLY OF GOD OF AMAPÁ
}

\begin{abstract}
In the Amapaense scenario, the denomination Assembly of God mobilized politically to elect its representatives from the beginning of the decade of 90, following the evangelical mobilization at national level with the slogan "Brother votes in brother", that seeks to elect politicians of the evangelical segment. Characterizing itself as the largest evangelical denomination in the State of Amapá (100,821 members according to IBGE 2010 data), the AD mobilizes itself politically to elect its peers and guarantee its interests. In this context, the present research has as objective to investigate the assembly support given to politicians of the legislature in Amapá, revealing how the candidate is chosen and how the support for these parliamentarians is articulated. In order to better support the research, the relationship between religion and politics in Brazil is analyzed, paying attention to the evangelical expansion of the Pentecost, especially the Assembly of God, which, through a change of stance, proselytism and political activity resulted in the multiplication of spaces social conditions occupied by this denomination in Brazilian society, not differing in Amapá, a State in which it changed its political
\end{abstract}


stance in the attempt to legitimize itself socially and politically. In the state, AD works from two perspectives, both with official applications and with political support. There is a heterogeneity with regard to this support because of the internal fragmentations and divisions themselves, so that $\mathrm{AD}$ alone can not elect a candidate from its membership. Through the subject in question, the theoretical methodological assumptions of the research focus on research of the qualitative type, where the techniques employed are content analysis, semi-structured interviews and bibliographic review.

Keywords: Pentecostal insurgency in politics. Assembly of God in the State of Amapá. Political Support. Official applications.

\section{Introdução}

O objetivo, com este trabalho, é investigar o envolvimento político da Assembleia de Deus (AD) no Estado do Amapá e o apoio dado a candidatos nas eleições para o legislativo (Deputado Estadual, Deputado Federal e Vereador). Busca-se através deste estudo compreender a insurgência política dos pentecostais da Assembleia de Deus no cenário político Brasileiro e desvelar como a AD se organiza para eleger seus representantes no campo político amapaense.

As mudanças no cenário religioso brasileiro se caracterizam pela queda do número de fiéis católicos e pelo aumento do número dos evangélicos, que passa dos 40 milhões no Brasil hoje. Repercutem mudanças também na conjuntura política do País. Nesse sentido, apresentam-se os dados do IBGE, os quais demonstram que o segmento evangélico foi o grupo religioso que mais cresceu no Brasil no período intercensitário. Em 2000, eles representavam 15,4\% da população. Em 2010 chegaram a 22,2\%, um aumento de cerca de 16 milhões de pessoas (de 26,2 milhões para 42,3 milhões). No entanto, o problema não se restringe tão somente à quantificação numérica da rubrica evangélica, mas também à forte e maciça participação na política partidária que vem passando por transformações ao longo dos anos, onde cada vez mais os evangélicos assumem cargos de prestígio na administração pública. Desta maneira, de acordo com Figueiredo Filho (2005), os grupos evangélicos no cenário cultural e político brasileiro constituem um fenômeno recente 
que surpreende pela linguagem difusa, pela atenção que a mídia lhes confere e pelos resultados eleitorais que conquistam.

Isto posto, procurar-se-á entender quais as relações que a denominação pentecostal ${ }^{4}$ Assembleia de Deus (AD) mantém com políticos no Amapá, uma vez que, na história da política nacional, esta denominação ofereceu e oferece apoio a parlamentares, sejam eles evangélicos convertidos ou mesmo aqueles que, em suas propostas políticas, beneficiam a instituição e seus membros.

Além disso, dado o atual momento da política brasileira, em que é possível notar uma gama de parlamentares evangélicos ocupando cargos públicos no executivo e no legislativo, e alguns deles tendo relações diretas com as Assembleias de Deus ${ }^{5}$, que contam com um forte aparato midiático com o intuito de salvaguardar os interesses do segmento evangélico através de projetos de leis e de discursos que defendem a "moral cristã" ${ }^{6}$ e a "família tradicional", propõe-se a tarefa de compreender como se estrutura esse apoio, a escolha e a construção da candidatura no Estado do Amapá, haja vista que a Assembleia de Deus é o segmento que mais conta com números de adeptos em todo o Estado (100.821 membros; $72 \%$ da população evangélica pentecostal $)^{7}$, no qual existem

4 A palavra pentecostal vem de Pentecostes, evento marcado pela efusão do Espírito Santo, cinquenta dias após a ascensão de Cristo. Pode-se considerar que a semente do pentecostalismo já estava plantada no protestantismo norte-americano através dos movimentos avivalistas dos séculos XVIII e XIX. O pentecostalismo teve origem nas doutrinas de John Wesley. O fundador do metodismo acreditava que o homem devia, após a justificação, dedicar-se à santificação. Desta concepção se apropriaram os evangelistas e teólogos que faziam parte do movimento de santificação, surgido nos EUA em meados do século XX. Esse movimento separou-se dos metodistas carismáticos, distinguindo conversão de santificação e denominando esta última de "batismo do Espírito Santo" (CAMPOS JR., 1995).

5 Demonstram-se aqui cargos de notoriedade como do ministro do Trabalho do atual Governo Temer, Ronaldo Nogueira (PTB-RS), que é pastor da Assembleia de Deus; e do ministro da Indústria e do Comércio, Marcos Pinheiro Linhares, presidente do PRB e Bispo licenciado da Igreja Universal do Reino de Deus.

6 Entende-se aqui a moral cristão como um conjunto de normas e valores que regulam a ação dos indivíduos. Nesse sentido, o meio evangélico é permeado por uma série de regras morais que determinam a forma de se comportar e agir do indivíduo na sociedade.

7 Em 2010 com o crescimento da população de 477.032 habitantes para 669.526, foram entrevistados pelos recenseadores do Censo IBGE (2010), 139.991 cidadãos sobre a vinculação institucional, e destes, 100.821 se declararam adeptos da Assembleia de Deus, que se mantém como a instituição com maior número de adeptos no Amapá. 
alguns parlamentares que receberam e recebem apoio desta denominação do pentecostalismo para suas candidaturas ao legislativo.

Esta pesquisa possui ainda o propósito de contribuir com os parcos estudos que relacionam política e religião no Estado do Amapá e mostrar a sua importância para a comunidade acadêmica e a sociedade Amapaense, uma vez que na literatura acadêmica local pouco se privilegia estabelecer tais discussões.

Para melhor situar o leitor sobre o assunto e mostrar o porquê escolheu-se a instituição Pentecostal Assembleia de Deus e suas relações com a política como instrumento de investigação, evidenciam-se os dados da Convenção Geral das Assembleias de Deus no Brasil (CGADB), os quais atestam que a instituição conseguiu eleger nas eleições do ano de 2014, em todo o Brasil, 24 deputados federais, dois a mais do que no pleito de 2010, e 23 deputados estaduais. O resultado poderia ser maior, porém, alguns candidatos bem votados não conseguiram se reeleger por causa da regra do coeficiente eleitoral ${ }^{8}$, o que fez com que outros menos votados entrassem em seus lugares ${ }^{9}$.

No Amapá, por exemplo, a $\mathrm{AD}$, por ser a maior instituição pentecostal do Estado, ocupa um considerável espaço de representatividade no cenário social e político ${ }^{10}$. Assim, os seus líderes buscam se articular para se manterem no acirrado mercado religioso amapaense, em que as tensões maiores, quando envolvem legitimidade social e política, ainda se dão entre os católicos e evangélicos, por serem grupos majoritários. Nesse segmento, para se legitimar socialmente e garantir seus interesses, a $\mathrm{AD}$ tem a preocupação em se mobilizar politicamente se valendo do discurso segundo o qual somente através da política é possível garantir

8 O quociente partidário define o número inicial de vagas que caberá a cada partido ou coligação que tenha alcançado o quociente eleitoral. "Determina-se para cada partido ou coligação o quociente partidário, dividindo-se pelo quociente eleitoral o número de votos válidos dados sob a mesma legenda ou coligação de legendas, desprezada a fração» (Código Eleitoral, art. 107). "Estarão eleitos tantos candidatos registrados por um partido ou coligação quantos o respectivo quociente partidário indicar, na ordem da votação nominal que cada um tenha recebido" (Código Eleitoral, art. 108). Informações no site: $<$ http://www.tse.jus.br/eleitor/glossario/termos-iniciados-com-a-letra-q\#quociente-eleitoral>. Acesso em: 26 nov. 2016.

9 Informações no site: <http://www.cpadnews.com.br/universo-cristao/24595/assembleiade-deus-elege-23-deputados-federais-.html> . Acesso em: 26 nov. 2016.

10 Disponível em: <http://g1.globo.com/ap/amapa/noticia/2014/06/indios-deixam-costumestradicionais-e-viram-evangelicos-em-aldeia-no-ap.html>. Acesso em: 02 out. 2016. 
os interesses e direitos de seus fiéis. Além disso, visualizam-se mudanças na forma de proselitismo.

$\mathrm{Na}$ tentativa de atrair adeptos, a AD possui diversos projetos sociais, sejam eles na recuperação de usuários de drogas, no envio de missionários a lugares ribeirinhos e a etnias indígenas ${ }^{11}$, no auxílio às pessoas de baixa renda que vivem em condições precárias em áreas periféricas do Estado, além de trabalhos sociais com jovens em ministérios, como a UMADMA - União da Mocidade Assembleiana -, programas de rádio ${ }^{12}$ e atrações midiáticas de grande notoriedade, como shows de cantores gospel, que mobilizam um grande público.

Esses dados levaram a pensar-se e indagar-se sobre a atuação e representação política de candidatos ligados à $\mathrm{AD}$ no Amapá e suas relações com a própria instituição. Os dados coletados em pesquisa de campo asseveram que há políticos ligados à $\mathrm{AD}$ desde o início da década de 90. Diversos membros ligados a denominações pentecostais ocupam cargos importantes na política ou já se candidataram para algum cargo público. Figuras importantes ligadas à $\mathrm{AD}$ se destacaram e se destacam no campo político amapaense, dentre as quais citam-se: o candidato Jefri Hippolyte ${ }^{13}$ (1994) (PSC), Valdenor Guedes ${ }^{14}$ (1990), ex-deputado federal e hoje presidente do Partido Social Cristão (PSC)

11 No que concerne ao projeto de mobilização social, elenca-se a fala do Pastor Rodrigo de Lima Junior, vice-presidente da AD a Pioneira: "Dessa forma, lembramos à sociedade que a igreja atende ao ser humano não apenas nas questões espirituais, mas também nas necessidades básicas. Em função disso, iniciamos o aniversário com esta ação social”. O pastor fez essa declaração na comemoração dos 98 anos de existência da instituição no Amapá em 2015, em que chamava atenção para as ações sociais prestadas à população amapaense, que envolviam serviços médicos, exames laboratoriais, consultas odontológicas, oftalmológicas, emissão de documentos. Sobre a atuação política, expõe-se a afirmação feita pelo pastor Lélis Washington Marinhos, presidente do Conselho Político Nacional da Convenção Geral das Assembleias de Deus no Brasil (CGADB), em uma entrevista concedida em 2014 ao Blog da Jornalista Amapaense Alcilene Cavalcante, que tratava de uma reportagem sobre apoio político a candidatos no Amapá: "Temos igrejas em 95\% dos municípios e isso favorece a divulgação dos candidatos. Nosso projeto é ter deputados em cada Estado". Nesse depoimento, identifica-se que, assim como em outros Estados da Federação, existe no Amapá uma mobilização do segmento pentecostal na tarefa de eleger seus representantes políticos.

12 A Assembleia de Deus de Santana (ADSAN) tem um programa numa estação de rádio (105,9 FM), que transmite cultos ao vivo e outros temas ligados ao grupo evangélico.

13 Em 2006 concorreu ao cargo de Deputado Estadual, não sendo eleito, pelo Partido Social Cristão (PSC). É ainda hoje assembleiano.

14 Sua primeira candidatura foi em 1988, pelo extinto Partido da Frente Liberal (PFL), ao cargo de vereador, mas não obteve êxito. Exerce atividade de pastor da Assembleia de Deus. 
no Amapá, Anab Monteiro ${ }^{15}$, candidato a deputado estadual em 2014 pelo (PSC), Fátima Pelaes ${ }^{16}$ (PMDB), que não foi reeleita em 2014 por conta do coeficiente eleitoral, Marcos Reategui Souza ${ }^{17}$ (PSC), eleito em 2014 deputado federal, Pastor Oliveira (PRB) ${ }^{18}$, eleito em 2014 também deputado federal, e Moisés Reategui de Souza (PSC) ${ }^{19}$, eleito deputado Estadual em 2014 por coeficiente eleitoral e ex-presidente da ALAP - Assembleia Legislativa de Macapá. A figura desses candidatos e o apoio assembleiano concedido às suas candidaturas serão mais bem explorados no decorrer deste estudo.

Por meio do tema em questão, os pressupostos teórico-metodológicos da pesquisa concentram-se na pesquisa do tipo qualitativa ${ }^{20}$, onde as técnicas empregadas são análises de conteúdo e entrevistas semiestruturadas.

Foram feitas visitas à Assembleia de Deus a Pioneira, localizada em Macapá, e a membros da Assembleia de Deus do Município de Santana (ADSAN) ${ }^{21}$, a fim de coletar dados e estabelecer contatos, bem como foram contatadas outras pessoas do meio evangélico.

15 Além de militante assembleiano, tem 42 anos, é casado, possui ensino superior e é policial civil. Já disputou eleições para outros cargos, por exemplo, o de vereador em 2012, mas não foi eleito.

16 Fátima Lúcia Pelaes, ou simplesmente Fátima Pelaes, é uma socióloga e política brasileira. Nasceu em 13 de fevereiro de 1959, em Macapá (AP). É Filha de Antônio Pelaes, técnico interino do C.R. Flamengo, e filiada ao PMDB. Deputada Federal, 1991-1995, AP, PFL. Dt. Posse: 01/02/1991; Deputada Federal, 1995-1999, AP, PFL. Dt. Posse: 01/02/1995; Deputada Federal, 1999-2003, AP, PSDB. Dt. Posse: 01/02/1999; Deputada Federal, 2007-2011, AP, PMDB. Dt. Posse: 01/02/2007.

17 Marcos Jose Reategui Souza nasceu em 06 de outubro de 1960 no Município de Macapá/ Ap. Possui ensino superior completo. Sua ocupação principal é Servidor Público Federal. Deputado Federal, 2015-2019, AP, PSC. Dt. Posse: 01/02/2015.

18 Ver-se-á que, mesmo esse candidato não sendo membro efetivo da Assembleia de Deus, recebeu apoio de fiéis isolados. Tem 48 anos, é casado e possui apenas o ensino médio completo.

19 Natural do Amapá nasceu na capital, Macapá, em 11 de janeiro de 1969. Possui nível superior completo (46 anos de idade). É filiado ao PSC - Partido Social Cristão. Foi eleito deputado estadual nas eleições de 2014.

20 Sobre o método de investigação utilizou-se a pesquisa qualitativa, que se caracteriza pela empiria e pela sistematização progressiva do conhecimento até a compreensão lógica interna do grupo ou do processo estudado (TURATO, 2005). É aquela capaz de incorporar a questão do significado e da intencionalidade como inerentes aos atos, às relações e às estruturas sociais, sendo essas últimas tomadas, tanto no seu advento quanto nas suas transformações, como construções humanas significativas (BARDIN, 1977).

21 Santana é o segundo município mais populoso do Amapá. Macapá e Santana totalizavam 557.322 habitantes em 2014, segundos dados do IBGE. 
Entrevistaram-se seis (6) interlocutore ${ }^{22}$ que, mesmo demonstrando certa relutância e desconfiança em serem entrevistados, foram essenciais para o andamento e concretização da pesquisa.

As entrevistas se concentraram ${ }^{23}$ no Pastor Presidente da Assembleia de Deus a Pioneira; na ex-assessora de um candidato, que é missionária e vice-presidente do Monte Sinai ${ }^{24}$ da Assembleia de Deus de Santana; num pastor da Assembleia de Deus do Ministério do Avivamento Macapá; num fiel da Assembleia de Deus que participou de alguns movimentos dentro da Igreja e acompanhou a escolha de candidatos; numa fiel da $\mathrm{AD}$ que frequenta algumas igrejas dissidentes; e num pastor do segmento Batista que frequentou a Assembleia de Deus e possui conhecimento sobre as formas de apoio político da AD.

22 O pastor é presidente da Pioneira, tem 72 anos e está há mais de 38 anos à frente dos projetos da Pioneira. É líder de mais de 200 templos em todo o Estado e tem mais de 30 mil fiéis sob o seu comando. Foi importante para que se pudesse entender quais as relações políticas que ele estabeleceu, quais eram os perfis dos candidatos escolhidos e os motivos que o levaram a se mobilizar politicamente. A interlocutora da Assembleia de Deus de Santana tem 49 anos e vivência há mais de vinte e sete anos na $\mathrm{AD}$. Além de ex-assessora política, contribuiu para definir quais os candidatos que sua igreja apoiou e os motivos que levam a rompimentos com candidatos. $\mathrm{O}$ pastor da $\mathrm{AD}$ do Avivamento, que está à frente de um ministério desde os anos 2000, auxiliou a entender que, embora ainda estejam trabalhando na candidatura oficial de um candidato, apoiam certo político por identificação, por ele fazer parte do meio assembleiano; também relatou como ocorre a escolha do candidato. Os dois fiéis, um do sexo masculino e outra do sexo feminino, com vivência na $\mathrm{AD}$ desde jovens, ambos com mais de 20 anos de trajetória, foram essenciais devido a vários fatos que presenciaram no que se refere às questões políticas envolvendo $\mathrm{AD}$, bem como observaram o envolvimento político desde a década de 90, viram modificações, alianças e rupturas. O pastor da Igreja Batista, de 32 anos, nascido em berço evangélico, se fez importante devido ao fato de ter sido da $\mathrm{AD}$ e ainda manter relações com membros da denominação. Em entrevistas, forneceu informações importantes sobre as fragmentações e dificuldades da $\mathrm{AD}$ em eleger, a partir de sua membresia, um candidato.

23 Informa-se que foram usados nomes fictícios para os interlocutores, haja vista que alguns deles não quiseram ter seus nomes expostos.

24 O Monte Sinai é o departamento feminino do chamado Círculo de Oração, que ocorre todas as quartas-feiras no templo maior da AD do Município de Santana. Os membros se reúnem em oração para orar pelos enfermos e mais necessitados. 


\section{A Mudança de postura política dos evangélicos e a participação Assembleiana a partir da década de $\mathbf{8 0}^{25}$}

No início, os primeiros protestantes a se instalarem no Brasil, no século XIX, tinham uma postura de afastamento da sociedade e de temas relacionados à política, principalmente os grupos pentecostais com posturas mais ascéticas e de negação do mundo. Defensores de uma ética relacionada aos valores, afirmavam sua postura apolítica. É o caso dos fundadores da AD no Brasil, Gunnar Vingren e Daniel Berg ${ }^{26}$, que achavam a política desnecessária. No entanto o crescimento e a expansão dessas denominações trouxeram modificações.

Porém, o processo de institucionalização dos grupos protestantes brasileiros, principalmente a partir da primeira década do século $\mathrm{XX}$, iria provocar o surgimento de um estilo de Igreja ou de Denominação, conforme a nomenclatura de Niebuhr (1992), na qual passava-se a existir uma maior integração com a sociedade em seus vários níveis (CAMPOS, 2005, p. 35).

Para Baptista (2007), os poucos protestantes que marcaram presença na política tiveram dificuldades, no que diz respeito, ao convencimento dos seus membros da importância de ocuparem cargos públicos. Tanto isso é verdade, que o autor informa que houve apenas um constituinte evangélico, em 1933-34 e em 1946²7, que foi o pastor metodista Guaracy Silveira.

No entanto, a presença evangélica na política tem a década de $80^{28}$ como um divisor de águas. No que tange à participação na política elei-

25 Ocorreu no século XX o aumento de adeptos ao protestantismo, o que facilitou a vinculação de políticos às igrejas e a setores evangélicos da população, o acesso ao campo político e acirrou as disputas entre católicos e evangélicos (FONSECA, 2011).

26 Daniel Berg nasceu em 19 de abril de 1884 na cidade de Vargön. Oriundo de uma família de Batistas, pobres, Berg viajou aos 18 anos de idade para o estado da Pensilvânia, nos Estados Unidos da América, onde trabalhou como operário; Gunnar Vingren nasceu em Ostra Husby, em 8 de agosto de 1879. Assim como Berg, veio de uma família pobre, de crentes da Igreja Batista (CAMPOS JR., 1995).

27 Nesse contexto, o período getulista é assinalado pela expressiva representação dos Católicos, que voltam a gozar de alguns espaços e privilégios que perderam com o advento da república.

28 Bonh (2004) atesta que em 1980, existiam 7,8 milhões de evangélicos no País. Registra ainda, que esse segmento religioso também crescia entre os legisladores e membros eleitos do Poder Executivo. 
toral do País, Reis (2011) informa que os protestantes, através de suas instituições e denominações, tiveram importante figura na arena política brasileira a partir da redemocratização, ocorrida na década de $80^{29}$.

Os pentecostais apresentaram uma mudança abrupta nas eleições de 1986, com destaque para a AD, para a Igreja Quadrangular - IQ - e a Igreja Universal do Reino de Deus - IURD -, que resolveram investir na eleição de representantes para o congresso constituinte (BAPTISTA, 2007). A principal mobilização evangélica em prol do envolvimento na política surgiu por parte da $\mathrm{AD}$, considerada a maior igreja evangélica do País, que alegava que, após a ditatura militar, o Governo poderia declarar o Brasil como país católico. Com isso, a AD resolveu lançar as primeiras candidaturas, que atingiram todos os Estados. Nesse período de mobilização a AD conseguiu eleger 14 deputados em 13 Estados (BAPTISTA, 2007).

O principal motivo da $\mathrm{AD}$ era fazer oposição à Igreja Católica e ter expressividade e reconhecimento na esfera pública. Com relação a esse período, a característica fundamental é a entrada em peso de deputados pentecostais, sobretudo provenientes da AD. Essa novidade implicou em nova dispersão geográfica e partidária, novo perfil social e nova trajetória política (FRESTON, 1993).

Conforme Baptista (2007), o ingresso institucional da AD para formar uma bancada no Congresso Nacional explorou o sentimento de medo dos fiéis. Um dos argumentos utilizados era que se estabeleceria no Brasil a religião católica como oficial; boatos de conspirações contra a liberdade religiosa alertavam para o reconhecimento legal de novos costumes, que para os evangélicos ameaçavam a instituição familiar. Lideranças da $\mathrm{AD}$ ressaltavam que a nova constituição poderia acolher a legalização do aborto, o casamento de homossexuais e a liberação da maconha (FRESTON, 1993).

Pierucci (1989) afirma que os parlamentares membros das denominações pentecostais e não pentecostais compõem uma espécie de "nova direita" 30 , na medida em que, além da defesa de bandeiras so-

29 No que se refere a esta redemocratização, é importante esclarecer que o golpe militar de 1964 é fator preponderante para a nova configuração política que surge a partir da década de 80; e o Ato Institucional (AI) n. 2 trouxe transformações para a atuação dos partidos políticos. Surge na década de 1980 o multipartidarismo, que leva a uma fragmentação do sistema partidário, culminando na criação de dezena de partidos. Compreende-se que neste período a Igreja Católica tem suas estruturas abaladas com o Estado e os evangélicos aproveitaram para se insurgir na arena política com força total.

30 Conhecidos como "Políticos de Cristos", essas igrejas lançam mão do slogan "irmão 
cioeconômicas direitistas tradicionais, eles se autoproclamam como os guardiões de uma moralidade familiar e social. Com a formação da bancada evangélica em 1986, as igrejas pentecostais, até então com postura apolítica, voltaram suas atenções para projetos evangelizadores e midiáticos ${ }^{31}$ (FRESTON, 1993).

A participação na política dos pentecostais pós-1986, como explica Baptista (2007), causou impacto pela articulação das corporações eclesiais, pois revelava objetivos de clara instrumentalização do espaço político, que visava à obtenção de recursos e privilégios para as instituições religiosas, através de práticas clientelistas manifestadas sem constrangimento (BAPTISTA, 2007).

Após esse período os evangélicos tiveram participação expressiva nos períodos eleitorais. Mariano e Pierucci (1992) ${ }^{32}$ demonstraram a presença dos evangélicos nas eleições de 1989, período em que o apoio evangélico se diversificou entre Collor de Melo (PRN) ${ }^{33}$ e Lula (PT) ${ }^{34}$.

vota em irmão" como estratégia para conseguir votos, alegando que os seus candidatos estavam aptos para governar. Defensores da moralidade política, os eleitores evangélicos eram induzidos a votar nesses políticos.

31 Concessões de TV e rádio têm sido importante moeda política, fruto do sistema político que incentiva a prática fisiológica e da lei da comunicação. A bancada evangélica ganhou pelo menos duas concessões de TV e sete de rádio. Em alguns casos, as rádios foram transferidas para as respectivas igrejas. Mas, como disse Daso Coimbra, "mais ou menos cem deputados tiveram estações de rádio, e se sete evangélicos receberam, isto não é nada dentro do Universo". Ou seja, os evangélicos estão bem adaptados à cultura política e não são vilões, como também não são o "sal da terra" de que fala sua própria retórica (FRESTON, 1993, p. 158).

32 Conforme Mariano e Pierucci (1992), havia por parte dos pentecostais um forte entusiasmo em lançar a candidatura de um representante protestante ao cargo de presidente do Brasil. Íris Rezende, Ex-Ministro da Agricultura do governo Sarney, foi indicado pelo (PMDB), que recebeu apoios da massa evangélica e de importantes empresários. Contudo, a candidatura de Rezende não foi adiante, pois foi derrotado pelos convencionais, que escolheram o presidente do (PMD) na época, Ulysses Guimarães (MARIANO; PIERUCCI, 1992). Com esta atitude, as lideranças se frustraram diante dos esforços de eleger um presidente, como eles próprios chamavam, "homem de Deus".

33 Toda a ideologia construída mobilizava os evangélicos a votarem contra Lula e a ver em Collor um caminho para que seus ideais fossem defendidos e continuassem a ter representação no País. Collor também aproveitava para se promover e conquistar mais eleitores evangélicos, indo a templos religiosos e fazendo alianças com seus principais representantes (MARIANO; PIERUCCI, 1992).

34 De um lado Collor de Melo (PRN) e de outro Lula (PT), em eleições que geraram embate e forças a favor e contra os respectivos candidatos. De um lado Collor, apoiado pelas principais lideranças evangélicas do período; e Lula, que tinha apenas uma parcela desse segmento ao seu favor. Os que defendiam a candidatura de Collor argumentavam que ele era a melhor opção para o Brasil, pois era um homem temente a Deus e não ameaçava a liberdade religiosa no Brasil. Diversos pastores de várias denominações pentecostais ofereceram apoio ao candidato, que ia desde a mobilização pelos meios de comunicação ligados a esses grupos até o apoio com boca de urna e atos que buscavam satanizar a candidatura do concorrente. 
Já em 1994, os evangélicos se dividiram no apoio a Lula e a Fernando Henrique Cardoso (FHC). Praticamente todas as igrejas evangélicas e pentecostais declararam apoio ao candidato do PSDB à Presidência, o "tucano" Fernando Henrique Cardoso (FONSECA, 2002).

Machado (2012) declara que as últimas três décadas vividas pela sociedade brasileira foram marcadas pela volta da democracia, pelo acirramento de competições do campo religioso e pela crescente participação dos pentecostais na política partidária e nas disputas eleitorais.

O ano de 2010 assinala o aumento do número dos evangélicos, como apontam os dados do IBGE, o que também significou maior atuação e articulação política de líderes de algumas denominações que saíram em defesa de seus interesses, como é o caso da AD, da IURD e da Igreja Batista. Tratando-se de período eleitoral em curso no País, esses segmentos religiosos buscaram se movimentar para salvaguardar suas inclinações ${ }^{35}$. Defensores de uma agenda conservadora, alguns desses segmentos defendem a "família tradicional" e a "moral cristã", e são contra a legalização do aborto e o casamento homoafetivo. No entanto, neste período houve uma divergência quanto ao apoio aos candidatos em disputa, e as assistências se concentraram entre os candidatos Dilma Rousseff do PT, Marina Silva do PV e José Serra do PSDB.

Rememora-se para o leitor que este período eleitoral no Brasil estava sinalizado pelas discussões sobre gênero e o papel político das mulheres. Com relação a esse cenário, Vital da Cunha e Lopes (2012) fazem recordar que, além da participação de duas candidatas mulheres ao cargo de presidente do Brasil, que reforçavam as possibilidades de ser eleita a primeira presidente mulher do País, estavam ocorrendo ainda as conquistas eleitorais de governos liderados por mulheres em outros países latino-americanos, o que favorecia e tornava essa imagem mais viva e forte. Nessa perspectiva, as mulheres passavam a exercer um papel cada vez mais representativo na político-partidária.

35 Machado (2012), ao escrever sobre esse período elucida que as lideranças da $\mathrm{AD}$, que se caracteriza como o maior grupo pentecostal do Brasil, no primeiro turno se viam divididas entre as candidaturas de Marina Silva, Dilma Rousseff e José Serra, ao passo que a IURD engajava-se na campanha petista ao mesmo tempo em que travava duros embates com outras denominações pentecostais na mídia eletrônica, impressa e digital, onde buscava desconstruir a imagem da candidata Dilma aos temas polêmicos como a descriminalização do aborto e da união civil de pessoas do mesmo sexo. 
Não só a presença feminina foi marcante, mas também temas como o aborto, sexualidade e pesquisas com células tronco geraram debates calorosos que alteraram os ânimos tantos dos políticos candidatos ao cargo da presidência como dos evangélicos conservadores. Assim, Machado (2012), acrescenta que temas como esses sempre foram alvo das análises de atores religiosos cristãos. No entanto, a autora aponta que, as inciativas dos dois governos Lula (PT) de instalar uma Comissão Tripartite de Revisão da Legislação Punitiva sobre o Aborto (2005), a realização da Audiência Pública sobre o Aborto em 27 de junho de 2007 e o lançamento de um novo Programa Nacional de Direitos Humanos (PNDH-3 $)^{36}$ em dezembro de 2009, teriam intensificado as ações e a reação coletiva de segmentos tradicionalistas (MACHADO, 2012).

Nesse segmento, Machado (2012) explica ainda que o PNDH-3 causou fortes reações tanto dos católicos quanto dos evangélicos conservadores, gerando controvérsias entre pastores, militantes dos movimentos sociais e os responsáveis pela elaboração do programa. "Em virtude da forte pressão das igrejas, a proposta original foi revista, mas as modificações não foram suficientes para eliminar as desconfianças dos grupos confessionais em relação ao PT e à sua futura candidata" (MACHADO, 2012, p. 30). Mediante esta conjuntura, acredita-se que havia, por parte de alguns líderes, religiosos certa hostilidade à candidata Dilma, caso que também foi visualizado neste ano (2016), uma vez que atrelavam a imagem dela como a favor da legalização do aborto, da união civil de pessoas do mesmo sexo e de outros temas correlacionados.

Vital Cunha e Lopes (2012) indicam que, meses antes do pleito de 2010, teve início uma série de conversas e negociações procurando estabelecer composições políticas que, entre outros agentes, tivessem

36 O primeiro ponto a se destacar é que o PNDH-3 foi precedido pelo PNDH-1 (1996), que enfatizou os direitos civis e políticos, e pelo PNDH-2 (2002), "que incorporou os direitos econômicos, sociais, culturais e ambientais". Subscrito por trinta e um ministérios diferentes, o PNDH-3 aborda distintos e controversos temas, como: a descriminalização do aborto; a criação de uma Comissão da Verdade para investigar os crimes cometidos na ditadura militar; a criação de redes de proteção dos Direitos Humanos de lésbicas, gays, bissexuais, travestis e transexuais; a regulação governamental dos meios de comunicação, tendo como ponto de referência os direitos humanos, entre outras coisas (MACHADO, 2012, p. 28-29). 
como parte atores e instituições mobilizados a partir das identidades religiosas (VITAL CUNHA; LOPES, 2012).

Ao se debruçar neste período eleitoral, os autores se empenham em demonstrar o apoio evangélico aos candidatos. Em relação à candidatura de Marina Silva, Vital Cunha e Lopes (2012) corroboram que a candidata se converteu à $\mathrm{AD}$ em 1990. Ainda que ela defenda causas de cunho ambiental, a filiação religiosa foi um elemento central nas caracterizações da formação do seu perfil durante a campanha.

Dentre os apoiadores de Marina Silva, estava uma liderança da AD, Sóstenes Apolo da Silva, que era responsável pelo diálogo religioso da campanha, lideranças do MIR (Ministério Internacional da Restauração), o Conselho Internacional de Pastores e Ministros do Estado de São Paulo, a Assembleia de Deus dos Últimos Dias e, por um determinado período da campanha, também o pastor Silas Malafaia, da Igreja Assembleia de Deus Ministério Vitória em Cristo (VITAL CUNHA; LOPES, 2012). Para Machado (2012), o crescimento da candidatura de Marina no primeiro turno foi resultado dos ataques dos líderes evangélicos ao PNDH-3 e às posições do PT e de Dilma sobre o tema aborto.

Outro fato importante evidenciado pelos autores refere-se, nas últimas semanas do primeiro turno, à mudança de posicionamento do Pastor Silas Malafaia ${ }^{37}$, que no segundo turno resolveu apoiar o candidato José Serra ${ }^{38}$. A mudança fora retificada sob a premissa de que

37 Acerca disso, Machado (2012) reitera que Malafaia, como formador de opinião pública no meio pentecostal do Rio de Janeiro, durante o primeiro turno, espalhou cerca de 600 outdoors em "favor da família e preservação da espécie humana", além de postar diversos vídeos no meio digital contra o PNDH-3, considerado por ele como "Plano Nacional da Vergonha Humana" e alertava aos evangélicos sobre a importância do voto, uma vez que as propostas ali inscritas seriam objeto de exame da próxima legislatura e sancionadas e/ou vetadas pelo poder executivo "(MACHADO, 2012, p. 33-34). "Acionando pânicos morais através dessas demandas, os vídeos sempre traziam como imagens do absurdo casais gays se beijando ou abraçados, travestis e transexuais em festas ou na Parada Gay e imagens (reais ou não) de embriões após a realização de aborto" (VITAL CUNHA; LOPES, 2012, p. 76).

38 Se as coisas pareciam ir bem para a campanha de Serra, que conseguiu constituir-se como um candidato contrário ao aborto, a campanha de Dilma não obteve o mesmo sucesso (VITAL CUNHA; LOPES, 2012). O pastor José Welligton Bezerra, presidente da convenção Geral das Assembleias de Deus, era um dos apoiadores fiéis do candidato do PSDB desde o lançamento de sua candidatura, e acionou os veículos de comunicação do seu grupo contra o PT e sua candidata (MACHADO, 2012, p. 33). 
Marina defendia um plesbicito que propunha possíveis mudanças na legislação do aborto (VITAL CUNHA; LOPES, 2012).

O pleito de 2010 foi marcado pelas controvérsias em torno do aborto. Também houve o apoio dividido entre os candidatos citados, porém cabe ressaltar que esta eleição se encontrava bastante polarizada, tais como em anos anteriores, entre PT e PSDB, disputando forças na arena política que acionavam oposições já conhecidas, como também produziam outras (VITA CUNHA; LOPES, 2012). Os "boatos", denúncias" ou "revelações", como pontuam Vital Cunha e Lopes (2012), favoreciam um partido em prol do enfraquecimento do outro.

Com isso, entende-se que os atores políticos nas disputas eleitorais se organizavam de formas diferenciadas. Possuíam candidatos próprios ligados por ideologias do grupo que estavam ligados aos outros por graus de correspondência e interesse maior ou menor e, ainda, com alguns que eram apenas alvo de rejeição.

Dessa forma, o jeito de fazer política pelos evangélicos se mostra na história como um fator importante para as alianças, obtenção do voto e a conquista de poderio político. É importante frisar que o voto e o apoio pentecostal são dados mediante as conjunturas políticas e sociais de uma determinada época, e uma das estratégias frequentemente utilizadas é a do estabelecimento de uma relação de clientelismo com fiéis/ eleitores em que se destacam ações em "centros sociais localizados em zonas mais carentes do Estado". Esse é um expediente comum entre os políticos, que seguem a lógica das permutas entre pequenos serviços sociais e os votos dos eleitores de pouca escolaridade e baixa renda (MACHADO; MARIZ, 2004).

Reforça-se ao leitor que os evangélicos, através de suas instituições e denominações, tiveram maior expressividade na política brasileira a partir da redemocratização ocorrida no País na década de 80. Uma das denominações de destaque foi a $\mathrm{AD}$, através de alianças partidárias, apoios, candidatos oficiais, estratégias midiáticas e ideológicas, mecanismos que lhes beneficiam tanto na representação político-social quanto na atração de mais fiéis.

Isto se reflete até os dias atuais, em que os evangélicos e a AD estão atuando fortemente para garantir seus interesses. Basta ligar a TV, ler o jornal diariamente ou acessar a internet para se deparar com 
as notícias relacionadas à relação entre evangélicos e política no Brasil, como a conquista da Câmara pelo deputado Eduardo Cunha do (PMDB), que é membro da Igreja Sara Nossa Terra e que tem relações amistosas com a AD; o aumento da bancada evangélica, que ultrapassa em número a feminista e a sindical; não esquecendo do Pastor Marcos Feliciano, que presidiu a Comissão dos Direitos Humanos, pertencente à ala conservadora.

O pleito de 2014 também foi palco dos pentecostais da $\mathrm{AD}$, não só elegendo representantes, como também votando a favor do impeachment da Presidente eleita Dilma Rousseff, da intervenção militar, além de atuarem fortemente na campanha em prol da "família tradicional Brasileira" e da "moral evangélica".

No entanto, problematiza-se ainda que estes grupos acabam, de certa forma, sendo responsáveis pela disseminação de ódio e intolerância aos LGBTS, fortalecem preconceitos, estigmatizam ${ }^{39}$ e hostilizam o outro que não faz parte do seu meio, e se apoiam claramente na separação entre o "joio e o trigo" para a definição do verdadeiro e do falso crente. E que vários de seus representantes políticos estiveram e estão envolvidos em escândalos de corrupção, como é o caso do próprio Eduardo Cunha, investigado pela operação Lava $\mathrm{Jato}^{40}$, além de seus

39 De acordo com Link e Phelan (2001, p. 377) “estigmas existem quando elementos de rotulação esteriotipização, separação, perda de status e discriminação ocorrem simultaneamente em uma situação de poder que permite tais componentes acontecerem". Link e Phelan (2001) falam que rotulação é um processo social de eleger uma determinada característica e aplicá-la a alguém, não indicando, necessariamente, que este indivíduo a possua. E é a partir dos rótulos empregados às pessoas estigmatizadas que os estereótipos são criados, gerando assim, o processo de esteriotipização (LINK; PHELAN, 2001, p. 369).

40 O Procurador Geral da República, Rodrigo Janot, enviou denúncia ao Supremo Tribunal Federal em que acusa o presidente da Câmara dos Deputados, Eduardo Cunha, de ter recebido propina no valor de, ao menos, US\$ 5 milhões para viabilizar a construção de dois navios-sondas da Petrobrás, no período entre junho de 2006 e outubro de 2012. Janot pediu a condenação de Cunha pelos crimes de corrupção passiva e lavagem de dinheiro e da ex-deputada Federal Solange Almeida, por ter participado de pressão pelo pagamento de valores retidos, incorrendo em corrupção passiva. Segundo a denúncia, dentro do esquema ilícito investigado na Operação Lava Jato, Eduardo Cunha recebeu vantagens indevidas para facilitar e viabilizar a contratação do estaleiro Samsung, responsável pela construção dos navios-sondas Petrobrás 10000 e Vitória 10000, sem licitação, por meio de contratos firmados em 2006 e 2007. A intermediação foi feita por Fernando Soares, operador ligado à Diretoria Internacional da Petrobrás, de indicação do partido PMDB. A propina foi oferecida, prometida e paga por Júlio Camargo. O Procurador-geral explicou que, para dar aparência lícita à movimentação das propinas acertadas, foram celebrados dois contratos de comissionamento entre a Samsung e a empresa Piemonte, de Júlio 
interesses políticos egoístas que atentam contra os preceitos das ideias da democracia brasileira.

Muitas de suas ações, sejam elas na política ou pelo viés midiático, atingem diretamente as subjetividades de muitos atores sociais, principalmente de grupos minoritários e contrários às suas inclinações. Não é válido contar somente a história dos evangélicos na política, é preciso compreender e refletir sobre a atuação política desse segmento religioso de forma crítica. Instiga-se o leitor a pensar: a quem de fato, eles estão beneficiando com suas manobras e alianças políticas? E questionar a própria laicidade brasileira e os limites de relações entre Estado e Igreja.

No Amapá, demonstra-se que existe uma preocupação da $\mathrm{AD}$ em se envolver com a política para garantir seus interesses, assim como os de seus membros. Com relação à sua participação na política, o pastor presidente da Pioneira entende que:

E do político a Igreja, ela não é um ente político, mas os seus fiéis são cidadãos... Seus fiéis pagam impostos, os seus fiéis, eles servem a pátria, servem né... Os seus fiéis, eles cumprem com os seus deveres para com a nação, eles votam e são votados como cidadãos. Nós somos cidadãos, não somos pessoas diferentes então... A Igreja, ela tem projetos... Ela precisa de leis que não venham contrapor as suas ações evangelísticas e opressoras da maioria discriminadora que rege o Brasil... E como nós devemos fazer isso, nós temos a plena consciência, trabalhando no legislativo. $\mathrm{O}$ legislativo é que constrói leis... Leis de quê? Leis do Silêncio, leis que restringem espaços... Espaços... Culturais, sociais, áreas de construção de Igrejas... Leis que restringem... A lei do silêncio! Nós temos que orar a Deus balbuciando o nome de Deus, porque senão o vizinho reclama que tá agredindo os seus ouvidos, tem a lei, fizeram a lei; então nos atentamos pra isso: que não adianta gritar, a lei está estabelecida e temos que cumprir, nós temos que estar no parlamento, no Parlamento Municipal, no Parlamento Estadual e no Parlamento Federal com pessoas que comungam de nossas ideias, de nossas angústias, de nossos problemas. Não são aqueles que a gente vota por votar que vão se envolver em nossos problemas, eles não se envolvem com os problemas dos outros, quanto mais dos evangélicos, que é uma minoria... Essa nossa consciência faz com que nós... É... Postulemos pessoas que são evangélicas e que nós

Camargo. Dessas comissões saíram as propinas prometidas a Fernando Soares, Eduardo Cunha e ao então diretor da área internacional da Petrobrás, Nestor Cerveró, que levou a questão à Diretoria Executiva e obteve a aprovação dos contratos relativos aos naviossondas, nos termos propostos pela Samsung. Disponível em: $<$ http://lavajato.mpf.mp.br/ todas-noticias>. Acesso em: 22 fev. 2016. 
votemos nela. Então, é por isso que os evangélicos, eles têm setenta e poucos deputados federais; então essa fatia tem sido útil para defender os pleitos dos evangélicos lá no parlamento... Se não fosse assim pior estaria... É... Queriam os deputados do PT e os da esquerda colocar as Igrejas, nesse... Nesse novo código civil. Queriam colocar as Igrejas como... Como uma agremiação, uma organização social, assim como o Flamengo, como o Trem, como a Associação Recreativa Banco do Brasil... Queriam nos colocar nesse nível jurídico. Então tem essa parcela de Deputados, que é significativa, que brigou em Brasília e nos tirou dessa categoria jurídica e nos colocou numa categoria, quer dizer [...].

O envolvimento político Assembleiano, como salienta o pastor, possibilita que os direitos dos fieis sejam garantidos. Contudo, é perceptível na fala do líder que os direitos dos quais ele fala são somente aqueles que contrapõem todo um sistema de moralidade e aspectos doutrinários da religião. Nesse caso observa-se na fala do interlocutor que a preocupação maior é com projetos que atingem os princípios doutrinários e as práticas pregadas pela instituição. E um dos modos para que se possa atuar contra essas ações é estar no meio político, participando e tendo voz.

\section{A Assembleia de Deus e seu envolvimento político no Estado do Amapá $^{41}$}

Logo nas primeiras visitas que foram feitas à Assembleia de Deus A Pioneira, em Macapá, para se estabelecer os primeiros contatos e tentar coletar as primeiras entrevistas, percebeu-se, ao ficar por algumas horas na sala de uma das lideranças, que a relação entre a instituição e a política era o assunto em voga naquele recinto. Observou-se, neste dia, que alguns pastores falavam sobre a escolha de candidatos para apoiar na legislatura de 2016 para o cargo de vereador. Já haviam sido realizadas algumas reuniões prévias por líderes de congregações ligadas à Pioneira que já tinham um candidato, o qual possuía uma trajetória no campo assembleiano: o filho da maior liderança da AD a Pioneira,

41 Esclarece-se que houve algumas dificuldades na coleta de dados para entender a relação política da $\mathrm{AD}$. Algumas pessoas se recusaram a dar entrevista, alegando que não se viam confortáveis em falar do envolvimento político da AD no Amapá. E, apesar de se ter tentado contatar alguns candidatos, não se conseguiu obter as entrevistas com eles. 
que nas eleições de 2016 para vereador estava cotado para ser candidato oficial da igreja. O próprio pastor presidente, em entrevista, confirmou a candidatura e se mostrou estar bem consciente sobre a importância de manter relações políticas-partidárias. Nas suas palavras: “[...] Agora nós precisamos também é... Saber que a Igreja enquanto instituição militante, quer dizer, aqui na terra é... Ela não é uma ilha, ela não pode viver... Desconectada... é... do econômico, do político, do social... Viu? [...]”.

Desta maneira, os trajetos da pesquisa permitiram entender que a AD no Amapá acompanhou uma campanha feita em nível nacional a partir da década de 80, que foi a do slogan "irmão vota irmão", a qual tinha o intuito de orientar seus membros a votarem e elegerem políticos evangélicos que defenderiam os interesses do grupo. Além disso, foi-se percebendo o óbvio: para apoiar ou ter um candidato oficial, as lideranças assembleianas analisam se esse político faz ou fez parte do meio evangélico ou se, ao menos, tem relações amistosas com a instituição.

Nesse sentido, o ator político precisa ao menos ter tido algum vínculo com a instituição, frequentar ou ter frequentado o meio pentecostal-evangélico, ocupar ou ter ocupado algum cargo de prestígio, seja na figura de pastor, na administração, ser um obreiro notável, ter feito parte de ministérios, ou seja, ter feito ou fazer parte da sua membresia privilegiada e, além disso, ter propostas que coincidam com as demandas e posturas da igreja e de seus fiéis. Necessário ter proximidade com os membros e que estes vislumbrem certo fascínio por ele. Como mencionou a interlocutora "Marcia" ao relatar sobre a escolha de um determinado candidato: "aquele que caiu nas graças do povo".

A seguir, apresentar-se-ão alguns candidatos que a AD já apoiou e apoia, por ordem cronológica, a partir dos anos 1990, evidenciando suas trajetórias na política e no meio evangélico pentecostal assembleiano.

Jefri José Braga Hippolyte, amapaense, nasceu no dia 10 de outubro de 1953. Iniciou sua carreira política nos anos 90, no Amapá, fazendo parte da primeira legislatura (1991-1994) ${ }^{42}$ como deputado estadual eleito pelo extinto PFL - Partido da Frente Liberal. Possui ensino médio completo. A vivência do candidato no assembleianismo teve início ainda na sua juventude: foi militante por muito tempo, fez

42 Disponível em: $<$ http://www.al.ap.gov.br/pagina.php?pg=historia $>$. Acesso em: 07 ago. 2016. 
parte do ministério de música com disco gravado, casou-se na igreja e, apesar de não ser pastor, tinha uma popularidade no meio evangélico ${ }^{43}$. Ainda hoje exerce essa função de pastor de uma congregação da AD.

Sob este enquadramento, o referido ator político foi um dos candidatos que recebeu apoio das lideranças assembleianas, nos anos 90, devido a toda a caminhada que desenvolveu na AD. Utiliza-se a fala do interlocutor "Valmir", fiel da AD, que afirma ter acompanhado todo esse processo:

[...] Não era pastor, mas era um obreiro; aí a liderança da Igreja viu nesse nome, o nome do Jefri Hippolyte, a possibilidade de eleger um candidato, e este era o argumento, que representaria os ideais da Assembleia de Deus... [...]. Isso foi em 90, e aí foi eleito, inclusive ele foi eleito para um mandato somente; não ficou mais devido a alguns descontentamentos, assim internos mesmo, na própria Assembleia; e posteriormente, apesar de ele receber apoio das lideranças, a própria massa não o acompanhou [...].

Algo que parece ser comum acontecer, que comentar-se-á mais adiante, é o candidato receber o apoio em determinado momento e contexto, e em outras candidaturas não o receber. Isso ocorre devido ao fato de o político não ter atendido às expectativas de lideranças maiores ou mesmo por haver outros candidatos evangélicos que despertam maiores interesses dos eleitores.

Ainda nos anos 90, evidencia-se o candidato Valdenor Guedes Soares, nascido em Macapá, no dia 31 de janeiro de 1954. Sua carreira política teve início em 1986, quando concorreu a uma vaga para a câmara dos deputados pelo também extinto PFL, mas não foi eleito. Em 1988, tentou uma vaga para vereador pelo PDT, mas novamente não obteve êxito. Somente em 1990 conseguiu eleger-se como deputado federal pelo PTB. Neste período, atuou no legislativo como membro titular das comissões de Ciência e Tecnologia, Comunicação e Informática e de Defesa Nacional, e como suplente da Comissão de Minas e Energia. O candidato exerceu ainda no Amapá a função de Diretor-Técnico da Caesa - Companhia de Água e Esgoto do Amapá -, foi coordenador estadual do meio ambiente da Secretaria Especial de Meio Ambiente do

43 Informações cedidas pelo interlocutor "Valmir", membro da AD, em entrevista. 
Amapá (SEMA-AP). Em 1994 foi reeleito pelo PP, sendo bem votado na capital, Macapá, e no Município de Santana.

Soares ainda concorreu a alguns mandatos nos anos de 1998, 2002 e 2008 pelo PSC, não sendo eleito. Durante algum tempo, foi pastor da AD e nos dias atuais assumiu a presidência do PSC no Amapá após a destituição de Moisés Souza da ALAP - Assembleia Legislativa do Amapá - por corrupção na sua administração. Devido a isso, o partido decidiu que seria mais viável outro nome para a presidência e acabou por escolher o ex-deputado federal Valdenor Guedes Soares ${ }^{44}$.

Sobre o apoio assembleiano ao candidato Valdenor Guedes Soares, esclarece-se que houve uma polarização. Se de um lado, nesse mesmo período, Jefri Hippolyte recebeu apoio maior da AD a Pioneira, Valdenor, por sua vez, recebeu apoio em peso da Assembleia de Deus do Município de Santana, na figura do Pastor Presidente, que se empenhou para elegê-lo, além do apoio da Assembleia de Deus do Avivamento e de outras igrejas menores. Mas, assim como o candidato anterior, apesar de ser lançada a candidatura em outros anos, Valdenor Guedes não foi bem-sucedido. O interlocutor "Valmir" explica:

[...] Valdenor Guerdes ficou por dois mandatos, se não me falha a memória, já tentou outras vezes, mas não se elegeu mais também... Por dois motivos, eu percebo: um é... Por não ter desenvolvido, eu penso assim um trabalho que tenha sido notório para a membresia, para os fiéis. Projetos de leis que beneficiassem os fiéis, que comtemplassem os fiéis; e os fiéis tiveram resistência em votar nele novamente [...].

Percebe-se, assim, que o interlocutor, na figura de fiel e frequentador da $\mathrm{AD}$, compreende que o candidato, ao não atender às expectativas dos líderes maiores da $\mathrm{AD}$ e ao não formular projetos que beneficiassem a membresia, fez com que a AD abrisse mão de oferecer seu apoio. Caso que aconteceu também com Jefri Hippolyte. Contudo, chama-se a atenção de que somente o voto evangélico assembleiano não é capaz de eleger um candidato.

44 Disponível em: $<$ http://www2.camara.leg.br/deputados/pesquisa/layouts_deputados_biografia?pk=74070\&tipo=1 $>$. Acesso em: 09 ago. 2016; Disponível em: $<$ http://g1.globo. com/ap/amapa/noticia/2016/04/moises-souza-perde-presidencia-do-psc-apos-destituicaona-alap.html>. Acesso em: 09 ago. 2016. 
Nessa continuidade, a fala do interlocutor parece demonstrar que o candidato não foi mais eleito devido à falta de votos dos assembleianos. No entanto, existem outros fatores que podem fazer com que um candidato não seja reeleito. Claro que os votos evangélicos fazem diferença na decisão política, mas como se pontuou, não são capazes de eleger um político no Amapá para o cargo de Deputado Federal, por exemplo, devido às próprias cisões que ocorrem no meio evangélico assembleiano e ao voto por identificação evangélica, em que o fiel vota não especificamente pelo candidato ser da $\mathrm{AD}$, mas sim por ser evangélico e atuar no campo.

Saindo dos anos 90 e entrando nos anos 2000, apresenta-se mais um candidato que recebeu apoio assembleiano. Ainda que ele não tenha recebido apoio em massa das lideranças das $\mathrm{AD}$ de maior prestígio, como recebeu Jefri Hipollyte e Valdenor Guedes, contou com o suporte de ministérios jovens, como o da UMDMA - União da Mocidade Assembleiana -, entidade na qual o candidato realizou diversos trabalhos e possui forte engajamento.

Trata-se da figura de Anab Monteiro, nascido em Macapá, em 06 de dezembro de 1973, casado, com ensino superior completo, e que exerce a profissão de policial civil. Em 2008, especificamente, concorreu ao pleito de Vereador pelo PSC e conseguiu o mandato graças ao vereador de quem ele era suplente envolver-se em escândalos de corrupção e ter o mandato cassado.

Concorreu ainda aos pleitos de 2012 e 2014 como Deputado Estadual pelo PSC, não sendo eleito, mas ainda assim continua mobilizando votos de fiéis da AD e do segmento evangélico. É possível ver nas redes sociais do candidato vídeos voltados para o público assembleiano e de como muitos membros veem nele a figura de um líder e "bom político". A fala a seguir é de um Pastor da AD do Avivamento, que, na falta de ter um candidato específico da igreja, afirmou ter apoiado Anab Monteiro:

[...] A Assembleia de Deus, falando um pouco assim, no caso, a Pioneira, eles têm vários candidatos, dentre eles eu conheço um que é muito meu amigo, que é o Anab Monteiro. Anab Monteiro em todas as eleições tem concorrido... Como o nosso ministério, nós ainda não tínhamos decidido por um candidato, nós estávamos apoiando Anab Monteiro, que é da Pio- 
neira, mas agora nos próximos pleitos nós queremos estar com o próprio candidato do nosso ministério [...].

O apoio desse Pastor e de sua congregação ao candidato se dá claramente devido aos laços que possuem e por identificação. Nesse caso, lembra-se aqui da afirmação de Fonseca (2002), ao explicar que os "eleitores evangélicos votam em seus pares, seus irmãos e pastores". Percebe-se, assim, que "Os políticos de Cristo" mantêm relação íntima com o meio do qual fazem parte. Esta fala ainda proporciona visualizar que existe já uma preocupação e articulação em andamento da $\mathrm{AD}$ do Avivamento para ter um candidato oficial que represente o ministério.

A candidata Fátima Lúcia Pelaes (PMDB) foi recentemente nomeada para a Secretaria de Políticas para Mulheres, vinculada ao Ministério da Justiça, do governo em exercício do Brasil, na figura de Michel Temer. Ex-presidente nacional do PMDB Mulher, ela ocupou mandatos de um modo quase vitalício no Estado do Amapá como deputada federal, desde 1991, só não se reelegendo em 2014 por conta do coeficiente eleitoral.

Nascida no Amapá em 13 de fevereiro de 1959, tem ensino superior completo com formação em Ciências Sociais, foi filiada ao PFL e ao PSDB. Foi reconhecida durante algum tempo como candidata oficial da AD no Amapá desde que se converteu ao pentecostalismo e iniciou sua trajetória no meio Assembleiano, como revelou o próprio presidente da $\mathrm{AD}$ a Pioneira e a ex-assessora da candidata, que também é presidente de um ministério da AD de Santana.

Pra Deputado Federal nós já tivemos candidatos nossos, da Igreja, ultimamente nós não temos. No tempo nós tínhamos a Fátima Pelaes, evangélica, hoje ela não tá no... no [...] (Pastor Presidente da Pioneira).

Foi lançado, teve uma assembleia extraordinária e nessa assembleia viram nossos irmãos que ela talvez tivesse a perspectiva de ser aprovada, como foi! ("Marcia").

Fátima Pelaes, como é possível ver, foi candidata oficial da $\mathrm{AD}$ e isso pode ser explicado devido a ela ser evangélica e comungar dos mesmos ideais dos grupos assembleianos. No parlamento, onde foi presidente da Frente Parlamentar da Família e Apoio à Vida, a Deputada se mostra contrária à legalização do aborto. Toda a sua privilegiada re- 
presentatividade na política nacional faz com que as lideranças da AD vislumbrem nela a candidata ideal para defender seus interesses no Congresso Nacional. Quanto maior prestígio tem o candidato, maiores possibilidades em ser um candidato oficial.

Dando continuidade às apresentações dos parlamentares que possuem envolvimento com A AD, cita-se o caso do Pastor Oliveira, o qual, ainda que não seja assembleiano, recebeu apoio de fiéis isolados, mesmo não sendo apoiado pelas grandes lideranças.

Carlos Antônio Oliveira Santos nasceu no Estado do Pará, em 24 de Abril de 1970, é casado, possui ensino médio completo e sua profissão é bancário $^{45}$. Em 2012, tentou uma vaga para vereador pelo PRB - Partido Republicano Brasileiro -, não sendo eleito. No pleito seguinte, em 2014, nas eleições estaduais, ainda pelo PRB, conseguiu uma das vagas para Deputado Estadual por regra de coeficiente eleitoral. Salienta-se que a legenda do PRB possui diversos candidatos que TÊM relações diretas com a Igreja Universal do Reino de Deus (IURD) ${ }^{46}$, tornando o partido a voz dos iurdianos no Congresso Nacional. No ano de 2014, alguns membros da $\mathrm{AD}$ votaram no candidato do PRB devido ao fato de ele transitar no meio evangélico pentecostal e ter predileções em comum com os assembleianos. Sobre isso, o interlocutor "Valmir" relata que:

O Pastor Oliveira, apesar de não ser da Assembleia de Deus, ele teve assim uma votação expressiva dos fiéis da Assembleia de Deus, mas também não foi sob a orientação da liderança assembleiana. Nós tivemos aí outro candidato da IURD também, da Igreja Universal do Reino de Deus, que era o candidato a Deputado Federal. Eu estava no dia no templo, e como a Igreja não tinha nesse pleito, não lembro o ano, um candidato para Deputado Federal, o Pastor sugeriu para que votassem nele porque era um cristão também.

Sobre isso, entende-se que, no Estado do Amapá, ao mesmo tempo em que há pastores de outras ramificações da $\mathrm{AD}$ que apoiam candidatos de outras denominações, existem aqueles que vão em sentido oposto. Recorda-se que se ouviu, nas dependências da Pioneira, pastores que

45 Disponível em: <http://www.al.ap.gov.br/pagina.php?pg=exibir_parlamentar\&iddeputado=61>. Acesso em: 11 ago. 2016.

46 Disponível em: <http://ultimosegundo.ig.com.br/politica/2012-07-15/voz-da-universalno-congresso-prb-quer-dobrar-numero-de-prefeitos-e-mira-2014.html $>$. Acesso em: 11 ago. 2016. 
falavam sobre a realização de cultos à noite para atrair fiéis da Igreja Universal. Sendo assim não se acredita que a Pioneira ou a Assembleia de Deus de Santana, as duas maiores que já competem entre si, apoiem candidatos do PRB. Além do mais concorda-se com Machado e Mariz (2004) quando afirmam que os atores políticos acionam a dimensão religiosa e desqualificam a capacidade de influência dos líderes dos grupos concorrentes com o intuito de aumentar seu potencial de negociação com os candidatos que buscam alianças ou apoios informais.

Evidencia-se outro caso curioso, de um político que tinha uma trajetória no meio evangélico Batista, mas passou a frequentar a $\mathrm{AD}$ e lá recebeu apoio político. Contou ainda com o apoio de congregações menores e da liderança maior da Assembleia de Deus de Santana na figura do Pastor Presidente.

O candidato em questão é Moisés Souza, ex-presidente da Assembleia Legislativa e ex-presidente do PSC. Foi afastado de ambos os cargos, como já mencionado, devido a várias investigações por corrupção e algumas condenações por fraude e licitações ${ }^{47}$. Moisés Souza ocupa um cargo no legislativo do Amapá desde o ano de $2007^{48}$.

Sobre a candidatura do Moisés Souza nós acompanhamos porque nós trabalhávamos lá no Jornal do Mário Passos que era sócio dele, do Jornal a Verdade... Ele era da Batista Memorial, e então o projeto foi idealizado pela Batista Memorial quando ele se elegeu a primeira vez... Ele já era cristão lá da Batista, declarado fiel, e depois migrou para a Assembleia de Deus, mas não chegou a ser o candidato da Igreja [...] ("Valmir").

Olha, nós temos vários candidatos um que foi apoiado e ganhou foi $\mathrm{o} \ldots \mathrm{O}$ deputado é... Meu Deus estava na minha cabeça agora e... Anab Monteiro! Foi um candidato que foi apoiado pela Igreja, mas que, no entanto, depois perdeu força porque a igreja buscou outros candidatos e ele, que era um nome forte no período em que participou das eleições, acabou não se reelegendo por conta da falta de apoio da $\mathrm{AD}$, que fechou parceria com candidatos que nem eram da igreja, como foi o caso de Moisés Souza [...] (Pastor da Igreja Batista e ex-assembleiano).

47 Ver notícias relacionadas em: < http://selesnafes.com/tag/moises-souza/>. Acesso em: 11 ago. 2016.

48 Disponível em: <http://www.al.ap.gov.br/pagina.php?pg=exibir_parlamentar\&iddeputado $=20>$. Acesso em: 11 ago. 2016. 
Analisando-se as falas dos interlocutores, na primeira ele está se referindo à $\mathrm{AD}$ a Pioneira, lugar no qual Moisés Souza não recebeu apoio e nem chegou a ser candidato oficial. Na outra chama-se a atenção para a possibilidade de o interlocutor estar se referindo à $\mathrm{AD}$ de Santana e Igrejas dissidentes menores. Assim traz-se, para reforçar, a fala de "Marcia" se referindo à Assembleia de Deus de Santana (ADSAN): “Como eu coloquei para você é... Há alguns anos atrás a igreja, ela ajudou o Deputado Moisés; tinha uma comunhão grande, como coloquei outrora pra você $[\ldots]$ ".

Nesse caso, "Marcia" relatou que, durante um longo período, a instituição de Santana apoiou o candidato Moisés devido a várias circunstâncias. Uma delas estava ligada ao fato de o candidato ter oferecido bolsas para missionários da igreja no valor de dez mil reais mensais destinadas a custear as despesas de seus deslocamentos para a evangelização em comunidades ribeirinhas do Amapá. Entretanto, a falta de cumprimento do candidato em manter essas bolsas fez com que a liderança cortasse os vínculos que tinha com ele; e arrisca-se aqui a afirmar que os escândalos de corrupção envolvendo o candidato também foram fatores para o afrouxamento dos laços.

A seguir, "Marcia" demonstra a insatisfação com a aliança política firmada, pois todos esperavam ações que beneficiassem a igreja, mas o candidato não manteve a promessa, reafirmando com isso que o apoio assembleiano e evangélico dá-se pela relação do clientelismo político, pela troca de favores (MACHADO; MARIZ, 2004).

Por duas vezes nós tentamos fazer isso, mas não deu certo, posso falar com convicção, a uns anos atrás, dois anos, quatro anos, oito anos atrás! Tentamos fazer isso, um vínculo para ajudar os missionários que estavam no campo. Então, devido o... o Deputado ser, entre aspas, da Igreja ele fez uma proposta: vamos colocar de liberar, naquela época, dez mil reais para se dar um salário, naquela época, que devia ser uns quinhentos, seiscentos reais pra cada missionário, é... Se manter no campo, mas infelizmente, assim, foi um fracasso. Foi um fracasso porque um ano assim, ele cumpriu com o contrato, mas no outro ano, meu filho, o contrato ele... Não é que foi quebrado, ele não passou mais a verba. Então, sabe o que aconteceu? Foram dez famílias que a gente não teve como... É... Eu posso dizer, assim, "se virar nos trinta" para manter essas famílias no campo. A minha Igreja em si, ela tem uma grande área é... É... Missionária. Apesar de ser uma instituição pequena, nós temos pra 
mais de quarenta missionários que são mantidos pela Igreja, pelos fiéis mesmo de Santana $[\ldots]$.

Por último, apresenta-se o candidato Marcos Reategui Souza. Nascido em 06 de outubro de 1960, no Estado do Amapá, é irmão de Moisés Souza, e foi eleito, em 2014, Deputado Federal pelo PSC. Possui nível superior completo. Profissionalmente, é servidor público federal ${ }^{49}$. Em 2013, foi afastado de suas funções de delegado da polícia federal devido a acusações de acesso a sistemas que não faziam parte de suas funções, além de ter sido réu em alguns processos do STF (Supremo Tribunal Federal) em ações penais por peculato, organização criminosa e crimes contra o sistema financeiro nacional. Anterior a esta eleição que concorreu, Reategui ocupou apenas cargos no serviço público ${ }^{50}$, e sua trajetória no campo político amapaense é recente.

Segundo os dados coletados, Marcos Reategui só conseguiu apoio assembleiano graças à trajetória política e religiosa do irmão Moisés Souza, que já tem uma longa carreira política e peregrinou no meio evangélico da $\mathrm{AD}$ e da Igreja Batista Memorial frequentando os cultos e estando próximo dos fiéis eleitores.

Nesse contexto, o capital simbólico do irmão e sua atuação no campo possibilitou que o candidato tivesse sucesso na política partidária e caísse nas "graças" do meio evangélico-pentecostal. Como confirmou o interlocutor: "O... O Marcos Reategui, que é Deputado Federal, que é Irmão do Moisés Souza, ele recebeu uma quantidade expressiva de votos dos membros da Assembleia de Deus por meio do Moisés Souza também [...]" ("Valmir").

Como visto, a AD oferece apoio e trabalha com candidaturas oficiais parlamentares ao legislativo no Amapá desde a década de 90, seguindo a campanha feita em nível nacional dos evangélicos, que prioriza a urgência de ter políticos no legislativo e no executivo. Assim, no Amapá, é notório o esforço das lideranças da AD em se articularem para eleger seus próprios candidatos a fim de garantir seus interesses.

\footnotetext{
49 Disponível em: <http://www.brasil247.com/pt/247/amapa247/124147/Marcos-Re\%C3\%A1 tegui-sai-da-cadeia-e-fica-afastado-da-PF.htm>. Acesso em: 11 ago. 2016.

50 Disponível em: $<$ http://www2.camara.leg.br/deputados/pesquisa/layouts_deputados_biografia?pk=178852>. Acesso em: 11 ago. 2016.
} 


\section{Como se articula o apoio assembleiano no Estado do Amapá}

Como já demonstrado acima, as características das motivações que levam a $\mathrm{AD}$ a apoiar um ator político ligam-se a alguns fatores, como por exemplo: vivência no meio evangélico e propostas que beneficiem diretamente o segmento. Sendo assim, desvelou-se que a AD organiza e estrutura esse apoio da seguinte forma:

\section{a) Realiza um pleito interno}

Esse processo é feito quando já existem nomes cotados para o apoio. É realizada uma reunião geral interna em que os pastores das congregações ligadas, sejam da AD a Pioneira, da ADSAN ou até mesmo de outras dissidentes menores que seguem a mesma lógica das denominações maiores, se organizam e fazem o que denominam de reuniões prévias. Os nomes são colocados em votação e aquele candidato que receber o maior número de votos é o escolhido. Como relata o Pastor Presidente da Pioneira:

E no nível estadual e municipal geralmente a gente indica candidatos da Igreja, e esses candidatos nos vamos é... Divulgar o seu nome para que a Igreja escolha. Por exemplo, nós fizemos uma prévia para escolher o candidato a vereador. Não é uma escolha imposta, é uma prévia entre os fiéis... Mais de quatro mil votaram e tem um nome já escolhido para ser indicado pra vereador, então veja, esse vai ser o candidato da Assembleia de Deus a Pioneira... É... Candidato a candidato, né... Porque ninguém pode dizer que... Candidato a candidato para é ... Ser apontado pela liderança a vereador. Nós vamos apontar, a gente não está cerceando a liberdade. Agora, esse que é o escolhido, esse vai ter a cobertura da liderança porque foi o escolhido numa prévia [...].

Problematizam-se dois aspectos na fala do Pastor Presidente. Primeiro, para as eleições para vereador, em 2016, já tem um candidato escolhido por essa estrutura, que é o seu filho, que será candidato oficial da $\mathrm{AD}$ a Pioneira, revelando assim que existe uma clara relação de influência e parentesco nessa escolha.

Outro ponto é que se desconfia que seja de fato um "plesbicito democrático" que conta com a participação efetiva das massas de fiéis da denominação. Pelas percepções e observações, verificou-se que, ao 
ser aprovado o apoio pelos Pastores Gerais, existe a certeza de que os outros membros irão aceitar o candidato devido à escolha ser pautada naquele que tem mais simpatia e proximidade com os fiéis, muito mais uma imposição sutil do que de fato uma escolha democrática com participação direta e decisiva dos fiéis da igreja com baixa renda e escolaridade, que não possuem cargos de prestígios e notoriedade na instituição, os que se arrisca aqui a tipificar como "fieis comuns", ou seja, os fiéis que vão apenas ao culto e não participam e se interessam pelas questões mais burocráticas da instituição; os que não se envolvem nos assuntos de cunho político partidária. Acredita-se existir então uma minoria que decide e os que aceitam por acreditarem nas suas lideranças religiosas. No entanto, isso não anula o fato de haver membros com influências e que possuem algum tipo de participação.

Em contraposição à fala do Pastor Presidente, apresenta-se o relato da interlocutora "Marcia", com cargo dentro da ADSAN, que informou sobre a estrutura do apoio, no entanto relatando apenas a presença de pastores nessas reuniões:

$\mathrm{Na}$ maioria das vezes quando aconteceu foi feita em Assembleia. O que é Assembleia? Nós temos as Assembleias gerais, onde os pastores gerais se reúnem e levam o nome dos irmãos, vamos supor, oito irmãos; e isso é uma votação. Se aquele um lá você ver que teve mais... Tem Mais... A perspectiva caiu mais na graça do povo; então foi aquele [...] ("Marcia").

Nesse sentido, isso ocorre pelo fato de o campo religioso ser pautado numa relação de hierarquias, onde uns possuem maior poder do que outros devido à posição que ocupam. Isso não é diferente na $\mathrm{AD}$ enquanto instituição em que todas as decisões perpassam, antes de tudo, pelas lideranças de maior prestígio, representadas nas figuras dos pastores presidentes, pastores de congregações e membros com maior notoriedade (os que possuem capital econômico, os que têm cargo na Administração e os envolvidos no meio político e com trabalhos sociais). Sendo assim, nessa hierarquia estabelecida alguns fiéis seriam os últimos a opinar e a tomar qualquer posicionamento decisivo sobre assuntos político-partidários. 


\section{b) O candidato precisa visitar os templos}

Posterior à concessão do apoio, o político escolhido deve visitar os templos assembleianos para manter uma relação de proximidade com os fiéis, no intuito de demonstrar sua disposição na defesa de seus interesses. Assim, os cultos, ambiente das práticas religiosas, são utilizados como mediadores da campanha política do candidato. Como detalha o interlocutor, pastor da igreja Batista e ex-assembleiano:

Eles subiam nos altares da Igreja, aqueles que nem eram evangélicos, mas ainda assim saudavam os irmãos como se fizessem parte do grupo evangélico da Igreja e pediam votos. E quando estes não pediam votos os próprios pastores das congregações faziam isso por eles, embora eles tivessem só lá sentando no altar da Igreja, mas os pastores mencionavam o nome deles e pediam votos, sim, em nome deles. Hoje não! Hoje eles visitam nossas Igrejas, eles sobem no palanque de festas de Igrejas, eles não falam o nome, mas só o fato de eles estarem ali e a lideranças abraçá-los, isso, na minha opinião, já se define como um pedido de votos [...].

Fica claro que as lideranças religiosas, juntamente com o ator político, acionam a dimensão religiosa como forma de obtenção de votos. Muitas vezes, embora não seja feito o pedido direto, apenas a presença do deputado ao lado da liderança ou transitando nas dependências da instituição já tem todo um significado, que é percebido pelos fiéis. Isso é feito no intuito de mostrar aos frequentadores em quem eles devem votar: naquele que é o mais apto para defender seus interesses, "o político de Cristo", o "enviado por Deus" para salvar a política e lutar pelos evangélicos.

\section{A heterogeneidade no apoio e o voto por identificação}

No Estado do Amapá, percebe-se que existe uma heterogeneidade com relação ao apoio concedido a esses candidatos devido às próprias cisões internas que ocorrem na $\mathrm{AD}$. Nesse caso, chama-se a atenção para as duas maiores instituições presente no Estado: a Pioneira, localizada na Capital, e a Assembleia de Deus do Município de Santana (AD$\mathrm{SAN}$ ), que se mostram contrárias no que se refere ao apoio: enquanto uma apoia um determinado candidato, a outra vai no sentindo oposto, demonstrando simpatia por outro nome. 
Há também as igrejas dissidentes menores que apoiam certo candidato, o qual foi descartado por essas duas grandes lideranças, e o voto de grupos isolados da $\mathrm{AD}$, por exemplo, grupos de jovens e outros ministérios.

Ademais, essas cisões são provocadas devido à falta de um poder centralizado, e os rompimentos ocorrem por questões políticas, ideológicas e administrativas. Por exemplo, é fácil uma congregação ligada à Pioneira se desmembrar e ter um líder próprio, como ocorreu com a Assembleia de Deus de Santana, que resolveu torna-se independente da Pioneira.

Seguindo essa lógica de rompimentos, a própria escolha do candidato é um fator para provocar rupturas. Isto ocorre devido ao fato de haver mais de um candidato evangélico que lança sua candidatura e espera contar com o apoio das lideranças da AD. Nesse caso, por ser escolhido apenas um, os outros decidem buscar outras formas de apoio e demonstram insatisfação com seus líderes, ocasionando rompimentos por questões político-partidárias. Sendo assim, sobre esse assunto o interlocutor, ao se referir ao plebiscito e a rompimentos por conta dele, demonstra que:

[...] embora isso não funcione na prática, porque você coloca cinco candidatos para concorrerem no plesbicito para ver quem a Igreja vai apoiar, e aqueles que acabam não ganhando, eles agem de forma... Eu poderia dizer de forma desleal, porque se você faz um plesbicito, você quer ganhar força para um determinado candidato; e na $\mathrm{AD}$ e isso não acontece. Por exemplo, se você for pastor da $\mathrm{AD}$ eu for pastor da $\mathrm{AD}$, e nós dois estamos concorrendo no plesbicito e a Igreja me escolhe, você se sente excluído, você vai, firma parceria em um outro partido político e você acaba concorrendo também. Nesse momento você divide a Igreja, porque têm pessoas que são seus amigos, que te acompanham, gostam do teu trabalho e têm aquelas que não acompanham. No final das contas nenhum dos dois ganha [...] (Pastor Batista e ex-assembleiano).

Nessas circunstâncias, essas rupturas geram impasses e embates de forças entre os atores envolvidos, que procuram se articular politicamente de outras formas. Além do mais, isso parece ser um dos fatores que fazem com que $\mathrm{AD}$ não consiga eleger sozinha um candidato proveniente de sua membresia. 
Em meio a isto, ainda tem o voto por identificação, processo pelo qual o fiel e frequentador da $\mathrm{AD}$ não vota no candidato oficial da igreja ou naquele que recebeu o apoio da liderança. Devido a essas rupturas internas ele vota, por exemplo, em um candidato evangélico que não precisa propriamente ter relações com a $\mathrm{AD}$, bastando que o político em sua campanha demonstre preocupação com os evangélicos (é o caso, como se destacou aqui, do Pastor Oliveira, que é da IURD, mas recebeu apoio de alguns fieis isolados da AD). Além disso, os interlocutores apontam que existe uma mudança de postura daqueles fiéis com maior grau de escolaridade, esclarecimento e consciência das conjunturas inseridas, que não votam no candidato indicado pelo pastor, e sim por interesses específicos. Fortalece-se tais argumentos com a fala do interlocutor "Valmir", que tem o seguinte entendimento:

[...] como eu falei, o público da década de 80 e primeira metade da década de 90 é diferente do público que a gente tem hoje; é um público muito mais esclarecido, muito mais politizado; é o público que tem formação. Então ele já faz uma maior seleção na hora de escolher o seu candidato e, portanto, a Assembleia de Deus atualmente não tem Deputado Estadual eleito pela Assembleia de Deus; tem assim candidatos de Igrejas coirmãs $[\ldots]$.

Compreende-se, sob esta perspectiva, que a $\mathrm{AD}$ não se difere do segmento evangélico como um todo, que é muito heterogêneo e, por isso, não consegue mobilizar-se para eleger um candidato. Desta maneira, somente o apoio assembleiano no Estado do Amapá não é suficiente para eleger um candidato, devido, muitas vezes, à falta de homogeneidade e consenso que existe no segmento.

Assim, os candidatos acionam outras categorias além do único e exclusivo voto assembleiano. Nesse caso, a maioria deles transita em outros grupos que não só os evangélicos. Contam ainda com os votos mobilizados pelos amigos, familiares e por outros lugares que frequentam, como, por exemplo, no meio profissional do qual que fazem parte. Até mesmo pela forma da campanha que desenvolvem e a extensão desta.

Com o apoio a essas candidaturas, os grupos de denominações assembleianas e seus líderes no Amapá se organizam para reivindicar 
interesses próprios e em prol do segmento religioso. Com as alianças e prestações de serviços a outros setores da sociedade, se obtém voto a partir do viés religioso. Dadas essas condições, os grupos evangélicos se valem de elementos presentes na própria cultura brasileira ${ }^{51}$.

\section{Considerações finais}

A $\mathrm{AD}$, tendo uma parcela expressiva de candidatos eleitos, tanto para a Câmara Federal quanto para o Senado Federal, é defensora de uma agenda conservadora pautada no combate a projetos que buscam beneficiar grupos minoritários e a ações que contrariam seus interesses doutrinários, ideológicos e políticos: assuntos como o casamento homoafetivo, legalização do aborto, drogas e outros que agridam a "moral evangélica".

Seus líderes se articulam, apoiam e lançam candidatos oficiais da igreja, com o objetivo de se insurgir no campo político, o qual entendem ser o meio possível para a defesa e manutenção de seu status quo.

Destarte, a AD, como maior segmento pentecostal do Brasil, elege representantes em todos os Estados da Federação. Não seria diferente no Amapá, em que se teve um crescimento assembleiano considerável nas últimas décadas, como se demonstrou. Nesse Estado, seus líderes também buscaram e buscam se articular, apoiando e lançando a candidatura de políticos oficiais da igreja com o intuito de elegê-los, a fim de obterem benefícios para suas instituições e terem seus representantes políticos.

No Amapá, a AD ofereceu apoio aos parlamentares do legislativo nos anos 90 seguindo a campanha feita em nível nacional pelos evangélicos sob o slogan "irmão vota em irmão". Nesse Estado, a AD trabalha sob duas perspectivas tanto com candidaturas oficiais, como através de apoio político a candidaturas. Existe uma heterogeneidade com relação a esse apoio devido às próprias fragmentações e cisões internas, fazendo com que AD não consiga sozinha eleger um candidato a partir de sua membresia.

51 Para eleger alguns representantes como, explica Machado (2003), a presença dos evangélicos na política do País teria ainda se fortalecido a partir de práticas clientelistas e coorporativas adotadas pelas lideranças religiosas junto a outros setores da sociedade, recorrendo a uma prática já existente na cultura brasileira. 


\section{Referências}

BAPTISTA, Saulo de Tarso Cerqueira. Cultura Política Brasileira, Práticas Pentecostais e Neopentecostais: a presença da Assembleia de Deus e da Igreja Universal do Reino de Deus no Congresso Nacional (1999-2006). 2007. Tese (Doutorado) - Ciências da Religião, Universidade Metodista de São Paulo, São Bernardo do Campo, 2007.

BARDIN, L. Análise de conteúdo. Lisboa: Edições 70 Ltda., 1977.

BOHN, Simone R. Evangélicos no Brasil: perfil socioeconômico, afinidades ideológicas e determinantes do comportamento eleitoral. Opinião Pública, v. 10, n. 2, 2004

CAMPOS, Leonildo Silveira. De Políticos de Cristo - Uma análise do comportamento político de protestantes históricos e pentecostais no Brasil. 2005.

CAMPOS JR., Luiz de Castro. Pentecostalismo. Sentidos da Palavra Divina. São Paulo: Geográfica, 1995.

FIGUEIREDO FILHO, Valdemar. Entre o palanque e o púlpito - mídia, religião e política. São Paulo: Anablume, 2005.

FONSECA, Alexandre B. C. Relações de privilégios estados, secularização e diversidade religiosa no Brasil. Rio de Janeiro: Novos Diálogos Editora, 2011.

. Secularização, pluralismo religioso e democracia no Brasil: Um estudo sobre evangélicos políticos nos 90. 2002. Tese (Doutorado). Faculdade de Sociologia. Universidade de São Paulo, São Paulo, 2002.

FRESTON, Paul. Protestantes e política no Brasil: da Constituinte ao impeachment. 304 f. 1993. Tese (Doutorado). Programa de Pós-graduação em Ciências Sociais. Instituto de Filosofia e Ciências Humanas. Universidade Estadual de Campinas, Campinas, SP, 1993.

Instituto Brasileiro de Geografia e Estatística - IBGE. 2010. Disponível em: <www.ibge.gov.br>. Acesso em: 20 nov. 2016.

. Disponível em: $<$ http://www.ibge.gov.br/estadosat/temas.php?sigla= ac\&tema $=$ censodemog2010_relig $>$. Acesso em: 26 nov. 2016.

LINK, B. G.; PHELAN, J. C. Conceptualizing stigma. Annual Review of Sociology, New York, n. 27, p. 363-385, 2001. Disponível em: <http://arjournals. annualreviews.org/>. Acesso em: 18 ago. 2016.

MACHADO, Maria das Dores Campos; MARIZ. Cecilia Loreto. Conflitos religiosos na arena política: o caso do Rio de Janeiro. Ciencias Sociales y Religion/Ciências Sociais e Religião, Porto Alegre, ano 6, n. 6, out. 2004. 
MACHADO, Maria das Dores Campos. Aborto e ativismo religioso nas eleições de 2010. Revista Brasileira de Ciência Política, Brasília, p. 25-54, jan./ abr. 2012.

MARIANO, Ricardo; PEIRUCCI, Flávio. O envolvimento dos pentecostais na eleição de Collor. Novos Estudos, n. 34, nov. 1992.

PIERUCCI, Antônio Flávio. Representantes de Deus em Brasília: a bancada evangélica na constituinte. Ciências Sociais Hoje, São Paulo, n. 11, p. 104$32,1989$.

REIS, M. V. F. Política e religião: o envolvimento dos católicos carismáticos na política brasileira. Dissertação (Mestrado). Ciência Política. Universidade Federal de São Carlos, São Carlos, 2011.

TURATO, E. R. Métodos qualitativos e quantitativos na área da saúde: definições, diferenças e seus objetos de pesquisa. Rev. Saúde Pública, São Paulo, v. 39, n. 3, p. 507-514, abr. 2005.

VITAL DA CUNHA, Christina; LOPES, Paulo Victor Leite. Religião e Política: uma análise da atuação de parlamentares evangélicos sobre direitos das mulheres e de LGBTs no Brasil. Rio de Janeiro: Fundação Heinrich Böll, 2012. 232p.

\section{Endereços de internet:}

<http://adpioneiramidia.webnode.com.br/>. Acesso em: 20 nov. 2016.

$<$ http://www.alcilenecavalcante.com.br/alcilene/principais-liderancas-evangelicas-fecham-apoio-com-a-pre-candidatura-do-promotor-moises-ao-governo-do-estado>. Acesso em: 30 set. 2016.

$<$ http://cidades.ibge.gov.br/xtras/perfil.php?codmun=160030>. Acesso em: 26 nov. 2016.

$<$ http://www.cpadnews.com.br/universo-cristao/24595/assembleia-de-deus-elege-23-deputados-federais-.html>. Acesso em: 26 nov. 2016.

$<$ http://g1.globo.com/ap/amapa/noticia/2015/06/assembleia-de-deus-celebra-98-anos-de-criacao-no-ap-e-espera-reunir-30-mil.html>. Acesso em: 18 ago. 2016.

$<$ http://montorilaraujo.blogspot.com.br/2011/07/primeira-igreja-pentecostaldemacapa.html>. Acesso em: 20 ago. 2016.

$<$ http://selesnafes.com/2015/10/entrevista-lider-da-assembleia-de-deus-fala-sobre-rachas-na-igreja-casamento-gay-e-politica/>. Acesso em: 26 nov. 2016. 